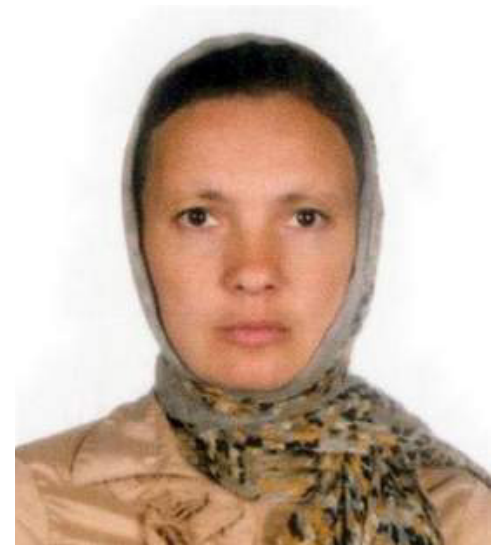

Тетяна Гриців,

аспірант,

Інститут проблем виховання Національної

Академії педагогічних наук України

(м. Київ)

Tetiana Hrytsiv,

Postgraduate Student,

Institute of Problems on Education of the National

Academy of Pedagogical Sciences of Ukraine

(Kyiv)

g.tanya76meta.ua@meta.ua

УДК 373.31:37.035.6

\title{
ВІКОВІ ОСОБЛИВОСТІ ВИХОВАННЯ ЦІННІСНОГО СТАВЛЕННЯ ДО БАТЬКІВЩИНИ ЗАСОБАМИ НАРОДНОЇ ПЕДАГОГІКИ У МОЛОДШИХ ШКОЛЯРІВ
}

\section{FORMING VALUES RELATED TO THE NATIVE LAND BY MEANS OF FOLK PEDAGOGY IN PRIMARY SCHOOL PUPILS: AGE PECULIARITIES}

У статті розкрито особливості виховання базових ціннісних ставлень (любові, гідності, патріотизму) до Батьківщини у системі народної педагогіки згідно емоційно-рефлексивного, інтелектуально-ціннісного, діяльнісно-вчинкового компонентів структури досліджуваної проблеми з урахуванням функцій та наукових підходів. Проаналізовано специфіку формування базових ціннісних ставлень у відповідності з віковими особливостями дітей початкових класів. Охарактеризовано закономірності та суперечності виховання ціннісного ставлення до Батьківщини у молодших школярів.

Ключові слова: Батьківщина, базові ціннісні ставлення, компоненти, функції, наукові підходи, вікові особливості.

The article reveals the peculiarities of forming the basic value attitudes (love, dignity, patriotism) to the Motherland in the system of folk pedagogy in accordance with the emotional-reflexive, intellectually valuable, action-taking components of the structure of the problem under consideration, taking into account functions and scientific approaches. Analyzing of the specific of the formation of basic valuable attitudes in accordance with the age characteristics of primary school children in article. Characterized by regularities and contradictions in the upbringing of valuable attitude towards the Motherland in junior pupils.

Keywords: Motherland, basic value attitudes, components, functions, scientific approaches, age characteristics.

В статье раскрыто особенности воспитания базовых ценностных отношений (любви, достоинства, патриотизма) к Родине в системе народной педагогики согласно эмоционально-рефлексивного, интеллектуально-ценностного, деятельностно-поступнического компонентов структуры исследуемой проблемы с учетом функций и научных подходов. Проанализирована специфика формирования базовых ценностных отношений в соответствии с возрастными особенностями детей начальных классов. Охарактеризованы закономерности и противоречия воспитания ценностного отношения к Родине у младших школьников.

Ключевые слова: Родина, базовые ценностные отношения, компоненты, функции, научные подходы, возрастные особенности.

Постановка проблеми в загальному вигляді та її зв'язок з важливими науковими та практичними завданнями. Політична та економічна криза в Україні, питання національної безпеки та глобалізаційні процеси ставлять виклики до українського суспільства, де пріоритетними мають бути проблема виховання ціннісного ставлення до Батьківщини. Сучасний етап розвитку України та державотворення зумовлюють необхідність відновлення культурної спадщини українського народу, яка є платформою націотворення.

Державні запити, відображені й у документах про освіту, підкреслюють необхідність виховання в підростаючого покоління любові до Батьківщини, формування громадянського обов'язку на основі національних і загальнолюдських духовних цінностей, утвердження якостей громадянина-патріота України як світоглядного чинника розвитку культурного й творчого потенціалу нашого народу [8, с.65]. Вчені переконані, що «у шкільному віці важливо формувати ціннісне ставлення особистості до свого народу, Батьківщини, держави, нації» [11, с. 124].

Актуальність проблеми виховання ціннісного ставлення до Батьківщини засобами народної педагогіки зумовлює до пошуку націєтворчих смислів та світоглядних орієнтирів починаючи вже з початкової школи у навчально-виховному процесі.

Процес формування системи цінностей, зокрема до Батьківщини, засобами народної педагогіки має свою специфіку на кожному віковому етапі розвитку особистості, що і необхідно врахувати у педагогічному процесі. 
Тому для того, щоб з'ясувати стан вихованості ціннісного ставлення до Батьківщини у молодших школярів, необхідно знати закономірності їх вікового розвитку, у чому в значній мірі допомагають думки і висновки видатних педагогів про особливості розвитку учнів початкових класів.

Аналіз останніх досліджень і публікацій, у яких започатковано розв'язання проблеми. Сучасне бачення та методологічні підходи щодо виховання ціннісних ставлень у молодших школярів відображено у працях І. Беха, С. Гарячої, О. Докукіної, К. Журби, В. Киричок, Г. Кирмач, Г. Назаренко, В. Рибалко, К. Чорної, І. Шкільної. Психологічні положення про закономірності розвитку дітей молодшого шкільного віку знаходимо у працях І. Беха, Л. Божович, В. Киричок, О. Савченко, О. Матвієнко. Специфіку розвитку молодших школярів досліджували В. Драгунов, Т. Драгунова, Л. Ітельсон. Особливості періодизації особистості молодшого школяра науково обґрунтували Л. Божович, І. Виготський, І. Кон, враховуючи всі сторони її діяльності в єдності - змістову, емоційну, мотиваційну та діяльнісну.

Формування мети статті. Метою статті є здійснити аналіз процесу формування ціннісних ставлень до Батьківщини у відповідності з віковими особливостями дітей початкових класів на основі компонентних складових та функцій структури ціннісного ставлення до Батьківщини з урахуванням наукових підходів до виховної діяльності.

Виклад основного матеріалу дослідження з повним обґрунтуванням отриманих наукових результатів. Всі провідні педагоги минулого особливого значення надавали меті виховання, яка в загальному зводилася до вироблення у дітей певних духовних та фізичних якостей і передачі їм деяких культурних вартостей.

В молодшому шкільному віці розвиток системи ціннісних ставлень супроводжується обґрунтовуванням мети, змісту діяльності. Вірогідність отримання позитивного результату виховної діяльності значно зростає, якщо остання спрямована на формування тих цінностей, які відповідають меті виховання. Мета виховання конкретизується певними завданнями.

Провідні завдання виховання молодших школярів у початковій школі зумовлено пріоритетними напрямами реформування виховання, визначеними Державною національною програмою «Освіта» (Україна 21століття), до яких належать:

- формування національної свідомості, любові до рідної землі, свого народу, бажання працювати задля розквіту держави, готовності її захищати;

- забезпечення духовної єдності поколінь, виховання поваги до батьків, жінки-матері, культури та історії свого народу;

- формування високої мовної культури, оволодіння українською мовою;

- прищеплення шанобливого ставлення до культури, звичаїв, традицій українців та представників інших націй, які мешкають в Україні;

- виховання духовної культури особистості; створення умов для вільного вибору нею своєї світоглядної позиції;

- утвердження принципів вселюдської моралі: правди, справедливості, патріотизму, доброти працелюбності, інших доброчинностей;

- формування творчої, працелюбної особистості, виховання цивілізованого господаря;

- забезпечення повноцінного фізичного розвитку дітей і молоді, охорони та зміцнення їх здоров'я;

- виховання поваги до Конституції, законодавства України, державної символіки;

- формування глибокого усвідомлення взаємозв'язку між ідеями свободи, правами людини та її громадською відповідальністю;

• забезпечення високої художньо-естетичної освіченості і вихованості особистості;

• формування екологічної культури людини, гармонії її відносин з природою;

- розвиток індивідуальних здібностей і талантів молоді, забезпечення умов їх самореалізації;

- формування у дітей і молоді уміння міжособистісного спілкування та підготовка їх до життя в умовах ринкових відносин [8, с.34].

Ці завдання окреслюють весь спектр виховання ціннісних ставлень до Батьківщини у молодших школярів і у системі національного виховання з урахуванням характерних ідей, поглядів народного виховання і виховного досвіду, методів і засобів виховання, що передаються від покоління до покоління й засвоюються як певні знання, уміння і навички. Через свої вікові особливості дитина молодшого шкільного віку ще не здатна до сприйняття повного спектру проявів ціннісного ставлення до Батьківщини.

Тому для досягнення поставленої мети у вихованні ціннісного ставлення до Батьківщини у молодших школярів засобами народної педагогіки, необхідно конкретизувати ці завдання згідно ціннісних ставлень любові, гідності, патріотизму у системі народної педагогіки на рівні емоційно-рефлексивного, інтелектуальноціннісного, діяльнісно-вчинкового компонентів структури досліджуваної проблеми.

У сучасній педагогічній науці молодший шкільний вік охоплює період навчання дитини у початковій школі 3 першого по четвертий клас (з 6 до 10 років). Хоча в різні періоди вік молодших школярів визначався по-різному, що було пов'язано з початком навчання в школі: з 9 років у минулому столітті; з 8-7 років за радянських часів. Також змінювався і термін навчання в школі з 3-х до 4-х років.

Центральним моментом молодшого шкільного віку є усвідомлення свого нового місця у системі суспільних відносин [7, с.147]. На цьому етапі у молодшого школяра формується ядро особистості, (моральні почуття, 
цінності, переживання), відбувається набуття моральної поведінки, він стає активним учасником у житті колективу, у виборі доручень, у виконанні улюблених справ [5, с.80].

Процес залучення дітей до цінностей українського народу сенситивний, оскільки саме в цей період закладаються основи світогляду і моральності, усвідомлюється необхідність відповідних якостей, визначаються взірці, формується моральна поведінка, які стануть основою світосприйняття молодої людини в минулому.

Сенситивність молодшого шкільного віку розкриває В. Киричок, визначаючи основні види потреб дітей цього віку, серед яких: потреба в емоційному контакті; в дружбі, товариськості, у повазі особистості, самоповазі. На думку дослідниці, саме в цей період розвиваються і зміцнюються внутрішні етичні інстанції, формуються моральні мотиви з дорослими та однолітками, більш усвідомленими стають почуття провини, сорому, обов'язку, відповідальності, емпатії тощо [3, с. 19].

Специфіку молодшого шкільного віку В. Драгунов, Т. Драгунова, Л. Ітельсон, І. Кон пов'язують з формуванням загальнообов'язкової повної і неповної освіти. Вони вважають, що молодший шкільний вік має скритий потенціал, який важливо вчасно розвивати і підтримувати. Діти молодшого шкільного віку психологічно готові до чіткого розуміння і засвоєння змісту моральних норм, правил та їх втілення у життя, однак дорослі не завжди враховують їхню готовність. Така поведінка дорослих призводить до того, що моральні норми і правила для молодших школярів набувають формального характеру і виконуються не через внутрішню необхідність, а під тиском тих чи інших зовнішніх обставин, у тому числі страху покарання [2, с. 97].

В розділі «Актуальные вопросы обучения и развития младшего школьника» С. Костюк констатує: «Розумове становлення дитини невіддільне від створення мотиваційних властивостей його особистості, від формування його пізнавальних інтересів, запитів, допитливості, моральних і естетичних почуттів, ціннісних орієнтацій» [4, с.150-155].

На закономірностях процесу виховання учнів початкових класів наголошує М. Стельмахович. За його твердженням, перша закономірність криється в органічному зв'язку й взаємодії численних факторів виховного впливу й тісному переплетенні між собою всіх напрямків виховання; друга - полягає в тому, що характер виховання дітей того чи іншого народу залежить від його державного устрою, світогляду, релігії й моралі, від рівня розвитку освіти, науки, економіки, культури, від його національних властивостей; третя закономірність виявляється в тому, що наслідки виховання бувають тим вагоміші, чим активнішим його вплив на внутрішню, духовну сферу особистості [8, с.36].

Оскільки ціннісне відношення людини не стільки реалізується у судженнях суб'єкта, скільки в емоційних реакціях на події, то емоції завжди ціннісно виражені. Первинна реакція людини, яка свідчить про її ціннісні пріоритети, завжди емоційна. Своєрідність емоційного процесу в молодшому шкільному віці полягає в емоційній вразливості молодших школярів, безпосередньому прояві і зовнішній виразності емоцій. Ці діти емоційно піддатливі до емоційних впливів [6, с. 207]. Тому при формуванні ціннісних ставлень до Батьківщини засобами народної педагогіки слід враховувати емоційну вразливість дитини молодшого шкільного віку, які виявляються у гострих переживаннях нового, здивуванні, сумнівах, радощах пізнання, що визначає емоційно-рефлексивний компонент. У дітей цього віку спостерігається глибока прив'язанність до родинного, соціального та природного оточення на рефлексивному рівні, що формують поняття малої Батьківщини, з чим вони себе ідентифікують. Тому у них до всього того, що окреслює поняття «малої Батьківщини» гостро виражені прояви любові, що $\epsilon$ платформою формування ціннісних ставлень любові до Батьківщини зокрема. Любов до Батьківщини $€$ визначальною синтетичною якістю громадянина і патріота, що поєднує емоційно-моральне й дієве ставлення до себе, до сім'ї, до інших людей, природи та суспільства [8, с.66].

Реалізація засобів народної педагогіки у навчально-виховному процесі в початковій школі сприяє виробленню ідентифікації і до національно-культурної сфери буття, в якій дитина безпосередньо перебуває. Засоби народної педагогіки, які в своїй основі несуть емоційну наповненість народної думки, дуже добре гармонізуються з емоційними проявами дітей початкових класів, що ефективно впливає на виховний процес. Задіюються розвивальна, активно-перетворююча та виховна функції виховання ціннісного ставлення до Батьківщини, які за рахунок емоційного навантаження стимулюють у дітей бажання, потреби, мотиви перебувати у аурі народного життя, спонукають активно вивчати та відтворювати звичаї і традиції свого народу.

Змістове наповнення засобів народної педагогіки має не тільки пізнавальне значення про життя українського народу, в ньому зафіксовані моральні норми та правила життя, що є основою формування ціннісних ставлень. Народна педагогіка в своїй основі реалізує запити програми нової української школи щодо компетентнісного підходу виховання, де знання, крім інформаційного, мають ще й ціннісне навантаження з виховною метою. Фольклор, казки, пісні, звичаї та традиції впливають на формування інтелектуальної сфери у дитини, збагачуючи її народними інструментами пізнання основ життя, за участю культурологічного підходу орієнтуючи молодших школярів на осмислення національних здобутків рідного народу. Відображені у засобах народної педагогіки норми і загальні принципи поведінки, які за допомогою різних технологій та форм роботи у ході навчальновиховного процесу засвоюються дітьми, впливають на формування ціннісних ставлень до Батьківщини, зокрема любові, гідності та патріотизму. Накопичення знань відповідного змісту, переломлення їх крізь призму свідомості дитини сприяє виробленню нею власного морального досвіду, ставлення до стереотипів поведінки та моральних зразків і переведення ціннісних ставлень українського народу у внутрішній план особистості, сферу чуттів, свідомості і поведінки. Активно реалізовуються функції виховання ціннісного ставлення до Батьківщини 
такі як розвивальна, аксіологічна, світоглядна. Таким чином за участю інтелектуально-ціннісного компонента відбувається передача досвіду поколінь, де формується національна свідомість.

у сучасних дослідженнях зазначається, що визначальним у вихованні є не зміст моральної вимоги, а психологічна організація дитини як суб'єкта діяльності [1, с.3].

Тому основою формування ціннісного ставлення до Батьківщини засобами народної педагогіки у молодшого школяра є його діяльність та спілкування у процесі засвоєння основ народної культури. Зміна вікових періодів передбачає зміну видів провідної діяльності. За О.М Леонтьєвим: «Провідна діяльність - це така діяльність, розвиток якої зумовлює найголовніші зміни в психічних процесах і психологічних особливостях особистості дитини на даній стадії її розвитку [9, с.285-286]. Перший шкільний рік дитини вимагає ігрових видів роботи і € перехідним від дошкільного дитинства. Крім того, безпосереднє емоційне спілкування з дорослими в ранньому віці розвиває у дитини потребу в у постійному контакті з ним. Немає необхідності створювати спеціальні виховні ситуації або тематично наповнювати міжособистісний зв'язок, бо реалізація засобів народної педагогіки все це передбачає. Засоби народної педагогіки, зокрема народні ігри, елементи традицій та звичаїв з фольклорним наповненням, де активно задіюється дитина, реалізуються за допомогою діяльнісновчинкового компоненту. 3 віком ускладнюються форми роботи з дітьми, від ігрової діяльності діти переходять до предметно-маніпуляційної діяльності, яка має більш суспільно-корисне значення. Уміння і навички моральноетичного змісту, які формуються у практичній діяльності на основі засобів народної педагогіки, безпосередньо мають вплив на поведінку молодшого школяра і виявляються у вчинках, що є одиничним актом його суспільно значущої діяльності. Вчинок визначається внутрішньою структурою, де в єдності виступають суб'єктивні чинники (потреби, інтереси, цілі, мотиви) та зовнішніми - обставинами, які склалися незалежно від волі дитини, а також суспільно-значущих наслідками дій. Виховання ціннісного ставлення до Батьківщини передбачає проектування вчинкових дій у дітей молодшого шкільного віку на основі народних норм і правил, зафіксованих у засобах народної педагогіки. Для дітей цього віку характерне наслідування за зразком, дитина керується набутими цінностями, опираючись на вже існуючий досвід. Вже у віці 9-10 років дитина спроможна робити вільний вибір на користь моральних цінностей українського народу, що регулюється внутрішніми спонукачами: совістю, гідністю, а також громадською думкою, думкою батьків, педагогів. Зміст певної цінності, заломлюючись через призму свідомості різних компонентів дитини, проявляється у її конкретних вчинках, де вже якісно виражені у ході діяльності дитини сформовані у неї ціннісні ставлення любові, гідності і патріотизму. Таким чином виховання ціннісного ставлення до Батьківщини зумовлена діяльнісним підходом, забезпечується такими функціями, як активно-перетворююча, морально-регулятивна, виховна та самовиховна.

Педагогіка визначає, що джерелами активності особистості, процесу формування її соціальних характеристик, моральних якостей та цінностей є суперечності, які виступають рушійною силою будь-якого процесу. Актуальність досліджуваної проблеми, яка обумовлена рядом суперечностей, визначає найвагомішим протиріччям між нагальною потребою виховання у молодших школярів ціннісного ставлення до Батьківщини та невикористанням повною мірою виховного потенціалу народознавчих дисциплін і поурочної роботи. Народно-педагогічний потенціал необхідний не лише у системі виховної практики, а й у навчально-освітньому процесі української школи для забезпечення національно-культурної ідентичності особистості школяра. Важливим є своєчасне вирішення цієї проблеми шляхом поглиблення змісту тематики чинних програм через народо-педагогічний аспект, активізація позаурочної системи роботи з метою реалізації засобів народної педагогіки, удосконалення педагогічних умов виховання дітей. Педагогічні упущення і помилки негативно відображаються на стані сформованості ціннісного ставлення до Батьківщини у молодших школярів засобами народної педагогіки. Недопустимим є нехтування народними традиціями та педагогічними досягненнями у виховній практиці;формальний підхід до виховної діяльності та небажання поліпшити справу; незнання специфіки молодшого шкільного віку; розмежованість виховних зусиль сім'ї та школи; невідповідність між словом вчителя та його поведінкою; конфлікт або протиставлення ціннісних ставлень до Батьківщини у життєвій практиці дитини початкової школи.

Значну роль у вихованні ціннісного ставлення до Батьківщини у молодших школярів засобами народної педагогіки відіграє позакласна робота. Протиріччя між необхідністю виховання у молодших школярів ціннісного ставлення до Батьківщини засобами народної педагогіки та незначним використанням проектної діяльності у початковій школі розв'язується у системі позаурочної роботи з дітьми. Ї̈̈ розуміємо як систему взаємодії вчителя та учнів, що узгоджується з навчальним процесом і логічно продовжує роботу на уроках з метою набуття ціннісних ставлень до Батьківщини засобами народної педагогіки. Забезпечення особистісно зорієнтованого підходу у процесі позакласного виховання полягає у сприянні проявам творчості та ініціативи дітей молодшого шкільного віку і педагогів, з урахуванням вікових особливостей дітей. у шестирічному віці домінує провідна ігрова діяльність з використанням емоційно-почуттєвих акцентів; забезпечуються зразки для наслідування у дітей 2-3 класів та конкретно-образне мислення; враховується бажання вибору у дітей 4-х класів 3 орієнтацією на народні норми і правила поведінки. Поєднання зусиль школи, родини, громадськості у вихованні ціннісного ставлення до Батьківщини підсилює виховний потенціал позакласної роботи, який ґрунтується на добровільній ініціативі й активності молодших школярів. Позакласна народознавча робота сприяє формуванню у молодших школярів ціннісного ставлення до Батьківщини, що є одним з головних завдань сучасної школи [6, с.210]. 
Висновки і перспективи подальших досліджень. Таким чином у молодших школярів відповідно до їх вікових особливостей формуються первинні, початкові ціннісні ставлення до Батьківщини, де базовими $є$ ціннісні ставлення любові, гідності та патріотизму. Структурні компоненти (емоційно-рефлексивний, інтелектуально-ціннісний, діяльнісновчинковий) з урахуванням відповідних функцій та наукових підходів виховної діяльності актуалізують виховання цих ціннісних ставлень до Батьківщини. Закономірності та суперечності виховного процесу у молодших школярів, які виникають у процесі формування ціннісних ставлень до Батьківщини засобами народної педагогіки, визначають необхідність використання народно-педагогічного потенціалу, як у навчально-виховному процесі початкової школи, так і в поурочній роботі з дітьми. Виховання ціннісного ставлення до Батьківщини, яке здійснюється за рахунок засобів народної педагогіки з урахуванням специфіки молодших школярів $є$ на сьогодні важливим і забезпечує становлення в учнів 1-4 класів національної самосвідомості та національно-культурної ідентичності особистості. Подальше дослідження потребує вивчення стану сформованості ціннісних ставлень до Батьківщини в початковій школі та пошук шляхів удосконалення і покращення ціннісних ставлень до Батьківщини за допомогою засобів народної педагогіки у молодших школярів.

1. Бех І.Д. Психологічна суть гуманізму у вихованні особистості / І.Д. Бех//Педагогіка і Психологія. - 1994. - №3. - С.3.

2. Возрастная и педагогическая психология: [учебник для студентов пед. ин- тов] / [В.В. Драгунов, Т.В. Драгунова, Л.Б. Ительсон и др.]; під ред. А.В. Петровського. - М.: Просвещение, 1979. - 288 с.

3. Киричок В.А. Гуманне ставлення до дитини: методологічний посібник [для вчителів] / Віра Андріївна Киричок. - Київ: Інфодрук, 2004. - 132с.

4. Костюк Г. С. Избранные психологические труды [под. ред. Л.Н, Прокопенко] / Г.С.Костюк. - М.: Педагогика, $1988 .-301$ с.

5. Основні орієнтири виховання учнів 1-12 класів загальноосвітніх навчальних закладів України: програма/ за ред. І.Д. Беха; Академія педагогічних наук України. - Тернопіль: Навчальна книга - Богдан, 2009. - 80 с.

6. Пташнік Н. М. Формування патріотично спрямованих орієнтацій молодших школярів засобами народознавства/Н.М. Пташнік//Проблеми освіти. Формування патріотизму та полікультурної компетентності майбутніх фахівців гуманітарно - педагогічного профілю: мат-ли XII Міжнар. конф.,19-21 бер. 20015 р. - Київ-Вінниця, 2015. - С.206-210.

7. Психологія: підручник[для студ. вищ. навч.закл.]/[Ю.Л. Трофімов, В.В. Рибалка, П. А. Гончарук та ін.; За ред.. Ю.Л. Трофімова]. - К.: Либідь, 1999. - 558 с.

8. Система патріотичного виховання дітей та учнівської молоді в умовах модернізацій них суспільних змін: навчально-методичний посібник / [авт. кол.:Бех І.Д., Журба К.О., Киричок В.А. та ін.]. - К.:Пед. думка. - 2011. - 240с.

9. Стельмахович М. Теорія і практика українського національного виховання: Посіб. для вчителя./М. Стельмахович. - ІваноФранківськ, 1996. - 179 с.

10. Леонтьев А. Н. К теории развития психіки в онтогенезе // Избр. Психолог. Произведения / А.Н. Леонтьев. - М., $1983 .-$ С. 285- 286.

11. Журба К.О. Теоретичні основи патріотичного виховання школярів /К.О. Журба, В.А. Киричок //Теоретико-методичні проблеми виховання дітей та учнівської молоді: Зб. наук. пр. -2008. - Вип. 11. - С.117-125.

\section{Reference}

1. Akademiia pedahohichnykh nauk Ukrainy.(2009). Osnovni oriientyry vykhovannia uchniv 1-12 klasiv zahalnoosvitnikh navchalnykh zakladiv Ukrainy: prohrama [The main guidelines for the education of pupils of grades 1-12 of secondary schools of Ukraine: the program], Ternopil: Navchalna knyha - Bohdan.

2. Bekh I. D.(1994). Psykholohichna sut humanizmu u vykhovanni osobystosti. Pedahohika i Psykholohiia [The psychological essence of humanism in the education of personality], № 3.

3. Drahunov V.V, Drahunova T.V., Ytelson L.B. y dr., \&Petrovskyi A.V. (Red.).(1979). Vozrastnaya i pedagogicheskaya psihologiya: uchebnik dlya studentov ped. in-tov [Age and pedagogical psychology] M.: Prosveshchenye.

4. Kyrychok V.A.(2004). Humanne stavlennia do dytyny: metodolohichnyi posibnyk [Humane attitude towards the child: a methodological manual]. Kyiv: Infodruk.

5. Kostyuk G. S., \& Prokopenko L.N. (Red.).(1988). Izbrannyie psihologicheskie trudyi [Selected psychological works].M.: Pedagogika

6. Leontev A.N. (1983). Izbr. Psiholog. Proizvedeniya. K teorii razvitiya psihiki v ontogeneze [To the theory of development of the psyche in ontogenesis], Moskva, pp. 285-286.

7. Ptashnik N. M. (2015). Problemy osvity. Formuvnnia patriotyzmu ta polikulturnoi kompetentnosti maibutnikh fakhivtsiv humanitarnopedahohichnoho profiliu. Formuvannia patriotychno spriamovanykh oriientatsii molodshykh shkoliariv zasobamy narodoznavstva: mat-ly XII Mizhnar. konf.,19-21 ber. [Formation of patriotic orientation of junior pupils by means of ethnography], Kyiv-Vinnytsia, pp. $206-210$.

8. Bekh I. D., Zhurba K. O., Kyrychyk V. A. (2011). Systema patriotychnoho vykhovannia ditei ta uchnivskoi molodi v umovakh modernizatsiinykh suspilnykh zmin: navchalno metodychnyi posibnyk. [The system of patriotic upbringing of children and young people in conditions of modernizing social changes], K.: Ped. Dumka, $240 \mathrm{p}$.

9. Stelmakhovych M.(1996). Teoriia i praktyka ukrainskoho natsionalnoho vykhovannia: Posib. dlia vchytelia [Theory and practice of Ukrainian national education], Ivano-Frankivsk.

10. Trofimov Yu. L., Rybalka V.V., Honcharuk P.A, ta in., \& Trofimova Yu. L.(Red.). (1999). Psykholohiia: pidruchnyk dlia stud. vyshch. navch.zakl.[Psychology], Kyiv: Lybid.

11. Zhurba K. O. Kyrychok V. A. ( 2008). Teoretychni osnovy patriotychnoho vykhovannia shkoliariv. [Theoretical foundations of patriotic education of schoolchildren] In Teoretyko-metodychni problemy vykhovannia ditei ta uchnivskoi molodi: Zb. nauk. pr., K., pp. 117 - 125.

Рецензент: Журба К.О., кандидат педагогічних наук, старший науковий співробітник, Інститут проблем виховання Національної академії педагогічних наук України 